\title{
STUDI POTENSI ENERGI GEOTHERMAL BLAWAN- IJEN, JAWA TIMUR BERDASARKAN METODE GRAVITY
}

\author{
Oleh: \\ Raehanayati $^{1}$, Arief Rachmansyah ${ }^{2}$ dan Sukir Maryanto ${ }^{3}$
}

\begin{abstract}
ABSTRAK: Penelitian ini merupakan studi awal untuk menentukan daerah yang memiliki potensi panasbumi berdasarkan pengukuran gayaberat di Blawan-Ijen, Jawa Timur. Pengukuran data primer dilakukan dengan menggunakan Gravitimeter LaCoste \& Romberg tipe G-1053. Data anomali Bouger dari hasil perhitungan koreksi-koreksi metode gayaberat kemudian dibawa ke bidang datar selanjutnya dilakukan pemisahan anomali regional dan anomali sisa dengan menggunakan metode kontinuasi ke atas. Hasil interpretasi terhadap anomali sisa yang dilakukan pada tiga penampang adalah penampang A-A' nilai densitasnya yaitu: $\rho_{I}=2.58 \mathrm{gr} / \mathrm{cm}^{3}, \rho_{2}=2.80 \mathrm{gr} / \mathrm{cm}^{3}, \rho_{3}=2.67 \mathrm{gr} / \mathrm{cm}^{3}$, dan $\rho_{4}=2.69 \mathrm{gr} / \mathrm{cm}^{3}$, sedangkan untuk penampang B-B' nilai densitasnya adalah $\rho_{1}=2.58 \mathrm{gr} / \mathrm{cm}^{3}, \rho_{2}=2.82 \mathrm{gr} / \mathrm{cm}^{3}, \rho_{3}=2.67 \mathrm{gr} / \mathrm{cm}^{3}$, dan untuk penampang C-C' nilai densitasnya yaitu $\rho_{1}=2.585 \mathrm{gr} / \mathrm{cm}^{3}, \rho_{2}=2.82 \mathrm{gr} / \mathrm{cm}^{3}, \rho_{3}=2.67$ $\mathrm{gr} / \mathrm{cm}^{3}$ dan $\rho_{4}=2.684 \mathrm{gr} / \mathrm{cm}^{3}$. Dari hasil pemodelan 2D dan 3D dapat terlihat bahwa pada daerah yang memiliki manifestasi air panas didominasi oleh batuan $\rho_{l}$ karena memiliki nilai densitas paling rendah yang berada pada daerah Blawan. Sehingga dapat disimpulkan bahwa reservoir panasbumi daerah Blawan-Ijen didominasi oleh batuan yang memiliki porositas tinggi (densitas rendah) dan tingkat permeabilitasnya tinggi dengan jumlah volume sebesar 101.20 juta $\mathrm{m}^{3}$.
\end{abstract}

Kata Kunci: Geothermal, Gravity, dan Blawan-Ijen

\begin{abstract}
This research is a reconnaissance study to know determine areas that have the potential of geothermal energy by measuring gravity at Blawan-Ijen, East Java. Measurement of primary data uses Gravitimeter Lacoste \& Romberg G-1053 type. Bouguer anomaly is projected to flat plane and upward continuation is used to separate the regional and residual anomaly. Results residual anomaly interpretation of the cross-section was performed on three cross sections A-A', B-B' and section C-C' shows that the density values are: for cross-section A-A' is $\left(\rho_{1}=2.58 \mathrm{gr} / \mathrm{cm}^{3}, \rho_{2}=2.80 \mathrm{gr} / \mathrm{cm}^{3}, \rho_{3}=2.67 \mathrm{gr} / \mathrm{cm}^{3}\right.$, dan $\left.\rho_{4}=2.69 \mathrm{gr} / \mathrm{cm}^{3}\right)$, section B-B' $\left(\rho_{1}=2.58 \mathrm{gr} / \mathrm{cm}^{3}, \rho_{2}=2.82 \mathrm{gr} / \mathrm{cm}^{3}, \rho_{3}=2.67 \mathrm{gr} / \mathrm{cm}^{3}\right)$ and section C-C' $\left(\rho_{1}=2.585 \mathrm{gr} / \mathrm{cm}^{3}, \rho_{2}=2.82\right.$ $\mathrm{gr} / \mathrm{cm}^{3}, \rho_{3}=2.67 \mathrm{gr} / \mathrm{cm}^{3}$ and $\rho_{4}=2.684 \mathrm{gr} / \mathrm{cm}^{3}$ ). From the 2D and 3D modeling results can be seen that in areas that have hot water manifestations are dominated by rock $\rho_{1}$ that is in the region Blawan. It can be concluded that the geothermal reservoir Blawan-Ijen area is dominated by a rock that has a high porosity (low density) and high permeability levels with a total volume of 101.20 million $\mathrm{m}^{3}$.
\end{abstract}

Key Word: Geothermal, Gravity, and Blawan-Ijen

\section{PENDAHULUAN}

Energi merupakan salah satu kebutuhan dasar manusia, karena dengan energi manusia dapat melakukan banyak hal. Seiring dengan pertambahan jumlah penduduk di Indonesia, maka kebutuhan energi juga semakin meningkat. Saat ini sebagian besar kebutuhan Indonesia dipenuhi dari bahan bakar fosil (migas dan batubara). Untuk dapat

\footnotetext{
${ }^{1}$ Program Pasca Sarjana Jurusan Fisika, FMIPA, Universitas Brawijaya (email:nanalaponk_89@yaho.com)

2 Jurusan Teknik Sipil, FT, Universitas Brawijaya

${ }^{3}$ Jurusan Fisika FMIPA, Universitas Brawijaya
} 
memenuhi kebutuhan energi di masa mendatang, pemerintah mengembangkan beberapa sumber energi alternatif, salah satunya adalah panasbumi atau geothermal [11].

Salah satu daerah yang diprediksi terdapat potensi geothermal adalah Blawan, Bodowoso yang terletak di Kompleks Gunung Ijen, Jawa Timur. Keberadaan pansbumi di lokasi ini ditandai oleh keberadaan mata air panas yang tersebar di bagian utara. Gunungapi Ijen merupakan salah satu gunungapi Kuarter yang memiliki aktivitas sedang sampai tinggi dan banyak solfatara dengan suhu mencapai $200^{\circ} \mathrm{C}$. Gunungapi ini dikenal, karena pembentukan endapan belerang yang tebal di bibir kawahnya. Dalam sejarah letusannya Gunung Ijen pernah mengalami letusan sangat besar, sehingga terbentuk kaldera dengan diameter hampir $5 \mathrm{~km}$. Di bagian utara Gunung Ijen (Blawan) terdapat batuan tua seperti breksi (breccia), lava dan basaltik-tuf. Bagian dalam kaldera didominasi oleh batuan muda akibat aktivitas gunung Ijen yaitu tuf, breksi (breccia) dan lava [6].

Metode gravity adalah suatu metode penyelidikan geofisika yang berdasarkan pada perbedaan medan gravity akibat perbedaan rapat massa batuan penyusun bawah permukaan bumi. Besaran fisis yang diukur dalam metode gravity adalah percepatan gravitasi bumi. Data percepatan gravity yang didapat selama pengukuran diolah menjadi anomali percepatan gravitasi bumi. Dari hasil pengolahan data tersebut dapat diketahui perbedaan rapat massa batuan, sehingga data tersebut dapat digunakan untuk menentukan struktur geologi bawah permukaan yang mengandung potensi energi geothermal di daerah penelitian [9].

Metode ini memiliki suatu kelebihan untuk survei awal yang dapat memberikan informasi yang cukup detail tentang struktur geologi dan kontras densitas batuan. Pada kasus geothermal perbedaan densitas batuan merupakan acuan dalam penyelidikan metode gravitasi. Dimana, daerah sumber panas di bawah permukaan bumi dapat menyebabkan perbedaan densitas dengan massa batuan disekitarnya [3].

Penelitian ini ditujukan untuk mengetahui posisi dan volume reservoir panas bumi berdasarkan hasil survei gravity. Metode gravity ini akan merekam kontras densitas antara reservoir dengan batuan sekitarnya, dan bentuk reservoir panasbumi. Karena suhu yang tinggi dan porositas tinggi, batuan reservoir panas bumi diinterpretasikan dari masa dengan densitas rendah. Penggunaan metode gravity dalam menganalisa densitas batuan dianggap tepat karena metode gravity memiliki respon yang sangat baik terhadap perbedaan densitas batuan di bawah permukaan. Dengan mengolah dan menginterpretasikan data kontras anomali Bouger maka dapat digunakan untuk memperkirakan struktur anomali densitas bawah permukaan yang diharapkan dapat memberi gambaran mengenai struktur bawah permukaan dan kondisi potensi geothermal di Blawan-Ijen.

Pengambilan data gravity dilakukan pada bulan Maret 2013 dengan menggunakan Gravitymeter LaCoste \& Romberg tipe G-1053, penentuan lokasi dan ketinggian titik pengamatan menggunakan GPS Garmin eTrex H. Sebelum melakukan pengukuran, terlebih dahulu dilakukan survey pendahuluan untuk mengetahui medan menentukan titiktitik pengukuran. Tahap selanjutnya adalah melakukan kalibrasi alat dan menentukan titik acuan (base station). Lokasi titik acuan harus tempat yang stabil atau mudah dijangkau. Penentuan titik acuan sangat penting, karena pengambilan data lapangan harus dilakukan secara looping, yaitu dimulai dari titik acuan yang telah ditentukan, dan berakhir pada titik 
tersebut. Titik acuan perlu diikatkan terlebih dahulu pada titik ikat yang sudah diketahui nilai mutlaknya.

Data medan gayaberat terukur selanjutnya dilakukan pengolahan dengan tahapan konversi data kedalam satuan gayaberat yaitu miliGal. koreksi pasang surut, koreksi drift, perhitungan gayaberat observasi, koreksi gayaberat normal, koreksi udara bebas, koreksi Bouger dan koreksi medan. Hasil dari pengolahan data gayaberat dari koreksi-koreksi tersebut merupakan nilai anomali Bouger lengkap. Nilai anomali Bouger lengkap ini masih berada pada topografi, sehingga perlu untuk memproyeksikan anomali Bouger tersebut ke bidang datar guna mempermudah dalam melakukan interpretasi data hasil pengolahan [12]. Selanjutnya nilai anomali yang terpapar di bidang datar dilakukan pemisahan anomali regional dan anomali sisa dengan menggunakan metode kontinuasi keatas (Upward Continuatian), kemudian dilakukan pemodelan dari anomali sisa. Pemodelan dilakukan berdasarkan interpretasi kualitatif dan informasi pendukung lainnya seperti peta geologi, peta topografi dan stratigrafi daerah penelitian sehingga hasil pemodelan yang diperoleh sesuai dengan yang diharapkan. Lintasan survei gravity dapat dilihat pada Gambar 1.
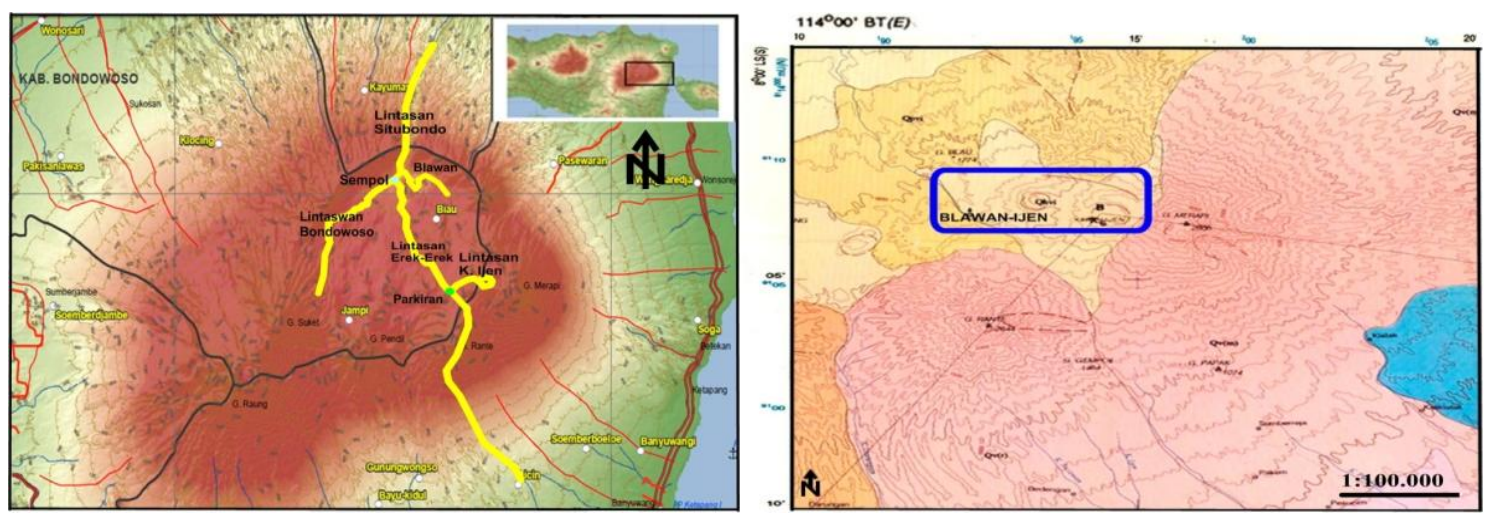

Gambar 1. Desain Survei Daerah Penelitian

\section{HASIL DAN PEMBAHASAN}

Dari hasil pengolahan data gravity di daerah Blawan Ijen diperoleh hasil penggambaran pola anomali Bouger (Gambar 2.) Anomali Bouger merupakan selisih antara harga gayaberat pengukuran yang telah direduksi ke bidang referensi ukuran (geoid) dengan harga gayaberat teoritis pada bidang referensi hitungan tertentu di suatu titik.

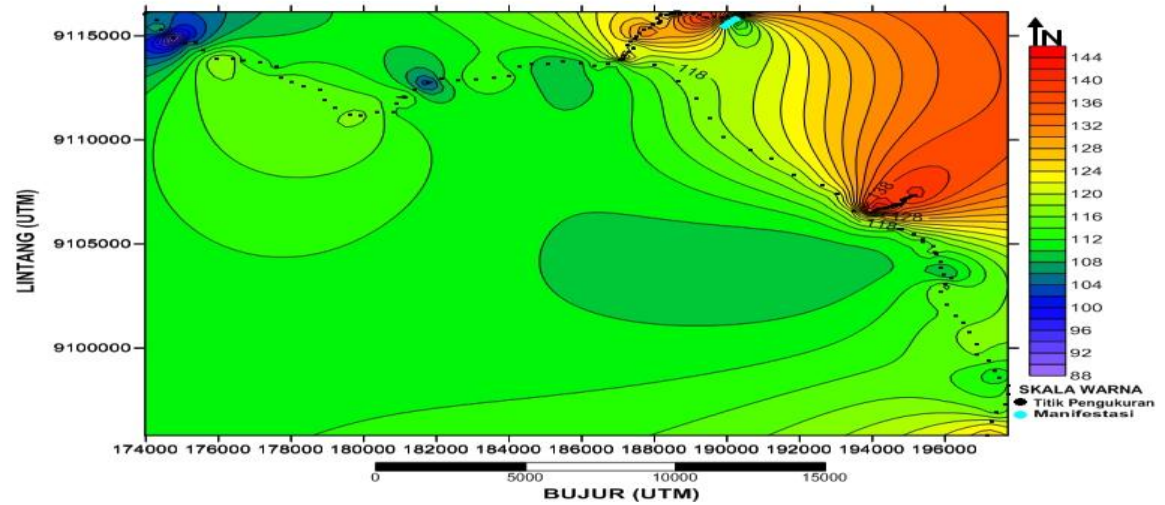

Gambar 2. Penggambaran Kontur Anomali Bouger 
Gambar 2 menunjukkan anomali Bouger daerah penelitian memiliki angka antara 88 sampai $144 \mathrm{mGal}$. Nilai anomali rendah berada di sebelah barat dan barat laut dari manifestasi air panas. Anomali tinggi berada di sebelah timur kawah ijen dan timur laut manifestasi air panas. Kontras densitas tinggi menunjukkan terdapat rekahan pada daerah tersebut. Sejalan dengan rekahan, terdapat deretan manifestasi air panas. Hal ini dapat terjadi karena pada daerah rekahan, air tanah yang telah terpanaskan dapat naik ke permukaan tanah melalui celah-celah batuan akibat rekahan tersebut.

\section{Reduksi Bidang Datar}

Untuk mempermudah interpretasi, data anomali Bouger lengkap yang berada pada topografi diproyeksikan ke bidang datar terlebih dahulu. Reduksi ke bidang datar perlu dilakukan karena nilai anomali Bougur yang sudah terkoreksi merupakan nilai yang masih terpapar pada topografi, yaitu terletak pada titik-titik yang tidak teratur dengan ketinggian yang bervariasi. Hal ini dapat menimbulkan kesulitan dalam melakukan interpretasi. Di bawah ini adalah kontur anomali bouger lengkap yang telah direduksi ke bidang datar seperti yang terlihat pada Gambar 3.

\section{Pemisahan Anomali Bouger Lengkap Dengan Kontinuasi Ke Atas}

Untuk menafsirkan geologi diperlukan anomali sisa yang diperoleh dari pemisahan anomali Bouguer menjadi anomali regional dan anomali sisa, dengan metode kontinuasi keatas, sehingga diperoleh nilai anomali regional dan anomali sisa. Anomali hasil dari reduksi bidang datar masih merupakan campuran anomali regional dan anomali sisa, sehingga perlu dilakukan proses selanjutnya untuk memisahkan kedua anomali tersebut yaitu proses kontinuasi ke atas. Di bawah ini adalah gambar anomli Bouger lengkap yang telah dikontinuasi sehingga mendapatkan kontur anomali sisa dan regional seperti pada Gambar 4 dan Gambar 5.

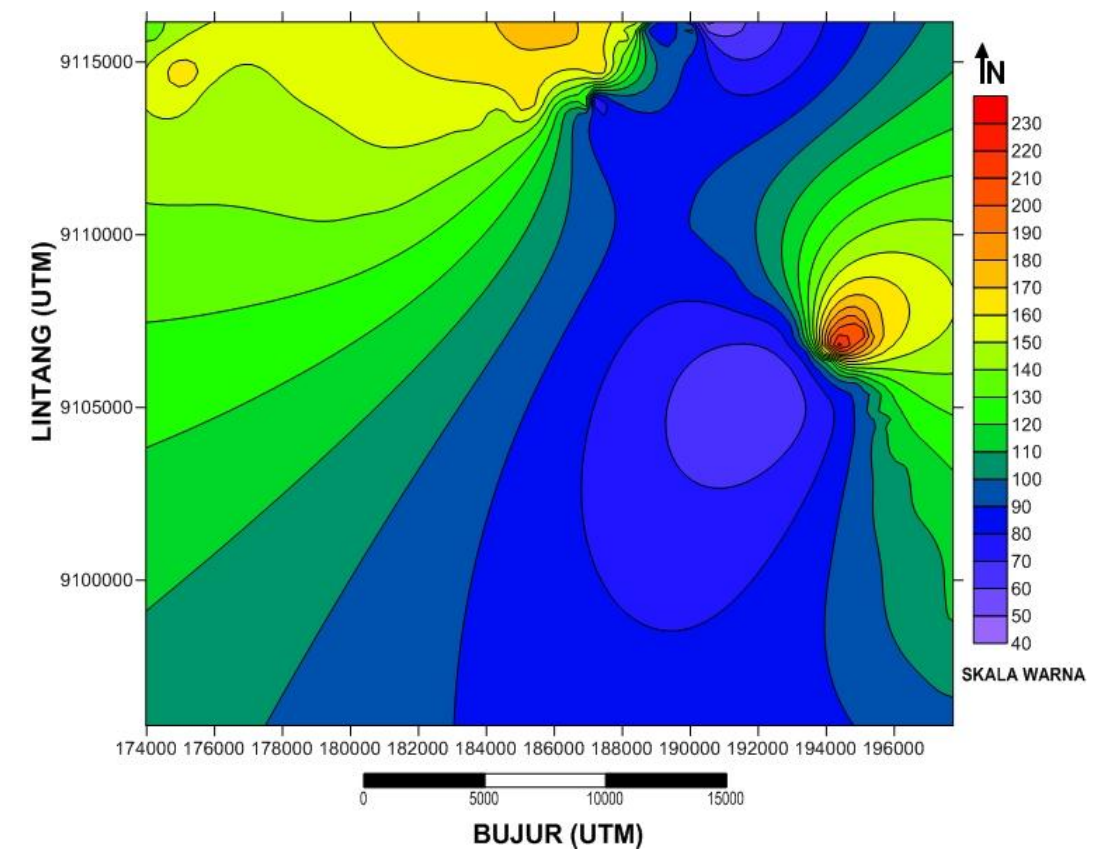

Gambar 3.Kontur Anomali Bouger Lengkap Setelah Direduksi 


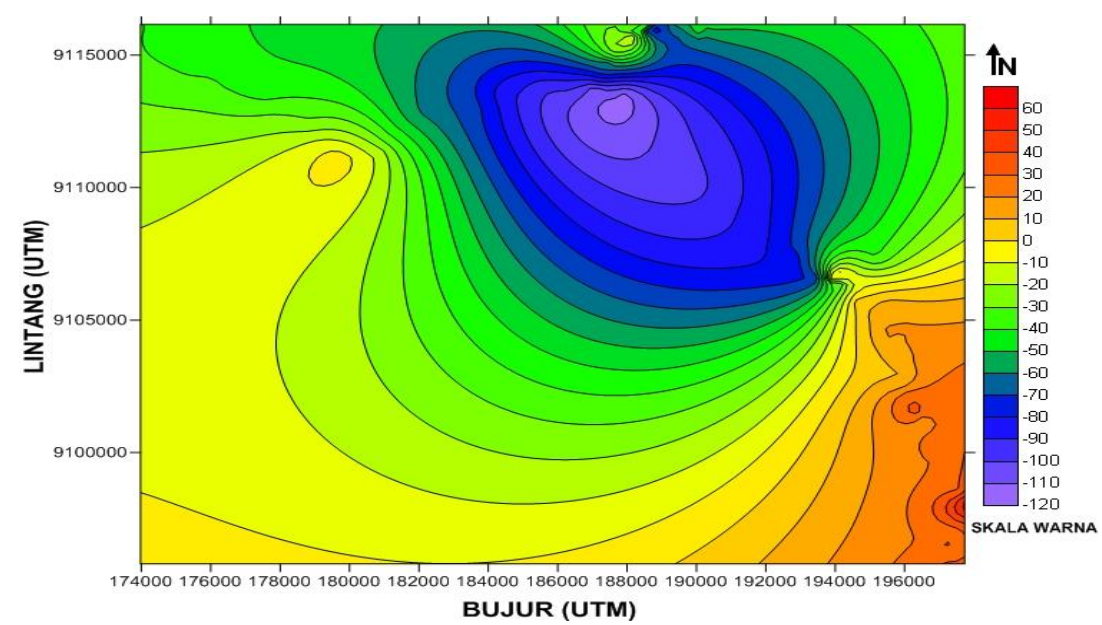

Gambar 4. Penggambaran Kontur Anomali Sisa Orde Tiga

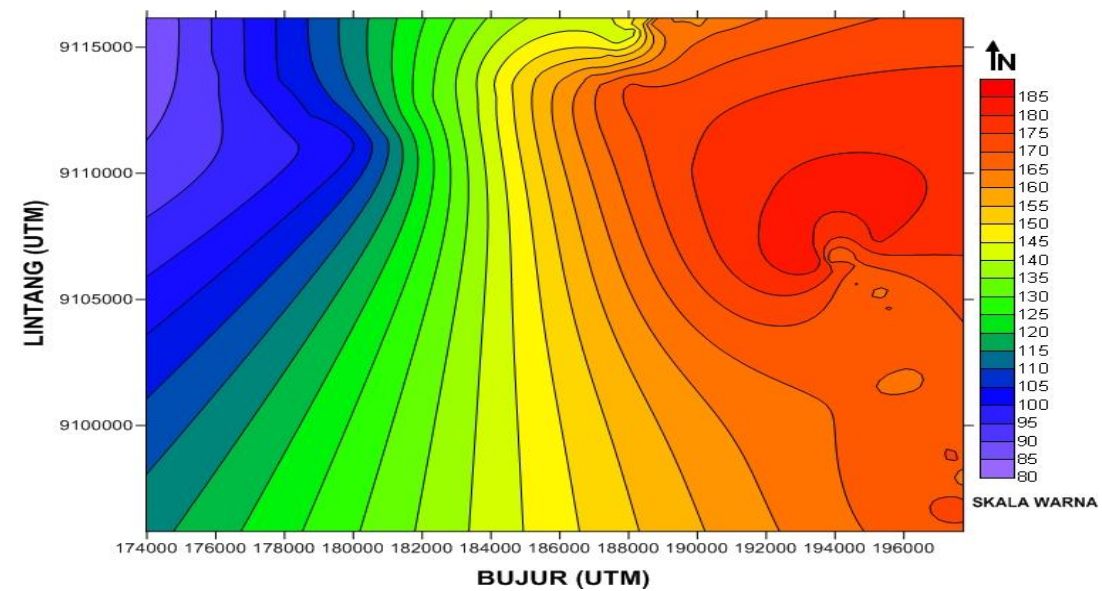

Gambar 5. Kontur Anomali Regional Orde Tiga

\section{Interpretasi Kuantitatif}

Interpretasi kuantitatif dilakukan dengan menganalisis penampang pola anomali sisa sepanjang lintasan tertentu. Pada penelitian ini dibuat tiga penampang anomali yaitu penampang A-A', penampang B-B' dan penampang C-C'. Langkah awal pemodelan adalah dengan mencoba berbagai kemungkinan model geologi bawah permukaan, penggunaan rapat massa penyusun daerah penelitian pada setiap lapisan dari model geologi yang dihasilkan ditentukan berdasarkan perkiraan model geologi (hasil interpretasi), ditunjang dengan rapat massa Telford dan rapat massa dari literatur lain. Interpretasi geologi secara kuantitatif dilakukan berdasarkan pemodelan sepanjang penampang anomali tertentu, sehingga dapat ditafsirkan geometri dari benda-benda geologi bawah permukaan yang menjadi penyebab timbulnya anomali. Pada penelitian ini pemodelan geologi dilakukan dengan bantuan software tertentu. Data masukan pada software ini berupa nilai jarak lintasan (dalam meter) dan nilai anomalinya, bentuk model tersebut tergambar sebagai anomali observasi sedangankan penampang hasil pemodelan geologi digambarkan sebagai anomali hitungan. Pemodelan ini dilakukan dengan metode trial dan error sehingga dalam pengerjaannya harus diiterasi sampai didapatkan ralat (error) terkecil.

Anomali Bouger penampang A-A', penampang B-B' dan penampang C-C' diambil berdasarkan hasil penafsiran kualitatif pola kontur anomali, dimana pada penampang A-A', 
B-B' dan C-C' memotong tinggian dan rendahan serta rapatan dan renggangan dengan nilai tertinggi $60 \mathrm{mGal}$ dan terendah adalah $-120 \mathrm{mGal}$. Lintasan pemodelan anomali sisa ditunjukkan pada Gambar 6.

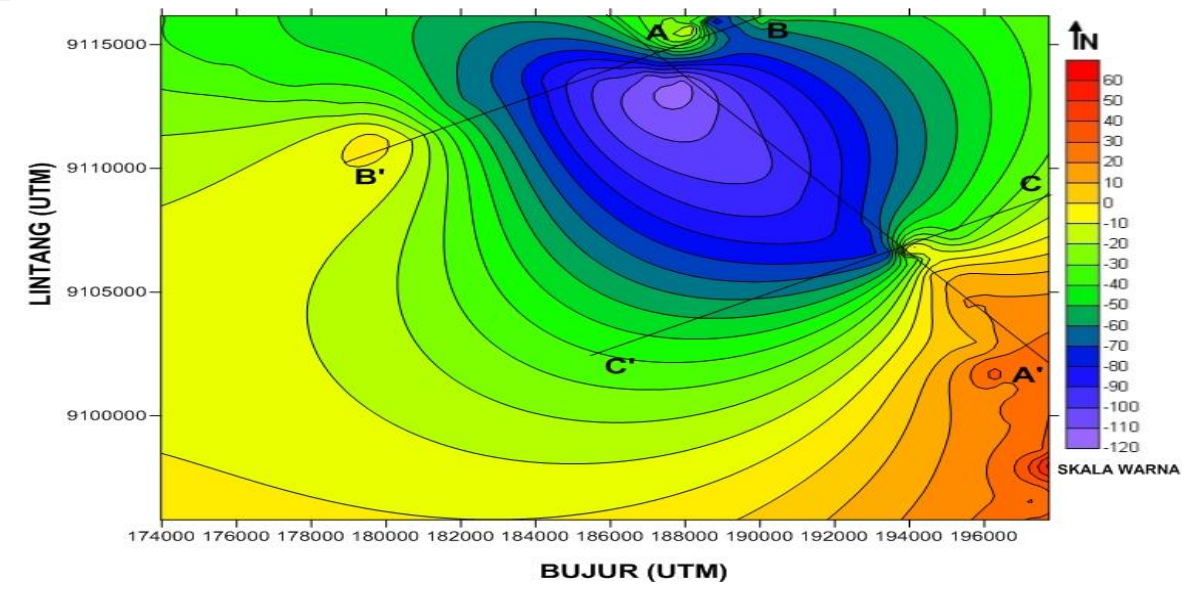

Gambar 6. Kontur Penampang Anomali Sisa

Di bawah ini adalah hasil pemodelan penampang A-A', penampang B-B' dan penampang C-C' seperti yang terlihat pada Gambar 7, Gambar 8 dan Gambar 9.

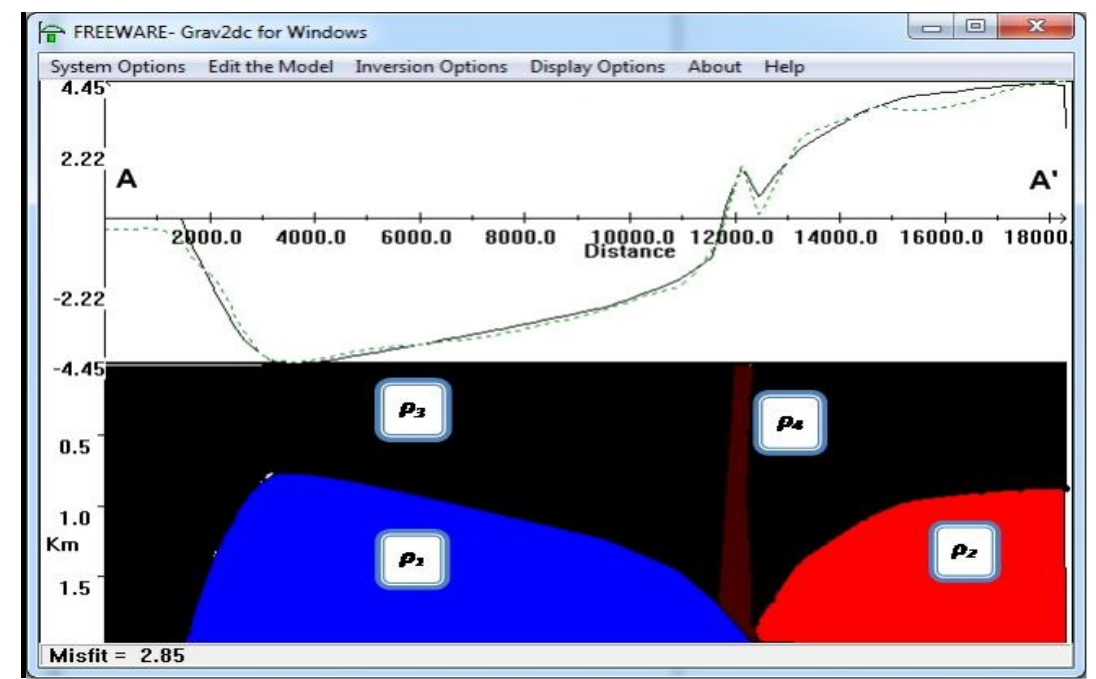

Gambar 7. Pemodelan 2D Penampang A-A'

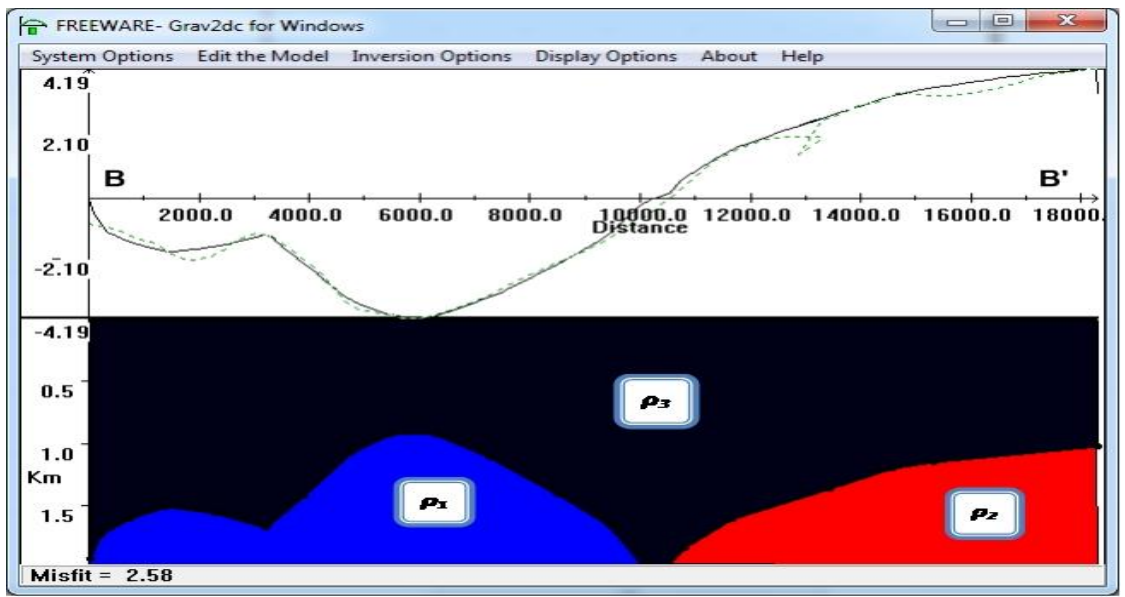

Gambar 8. Pemodelan 2D Penampang B-B' 


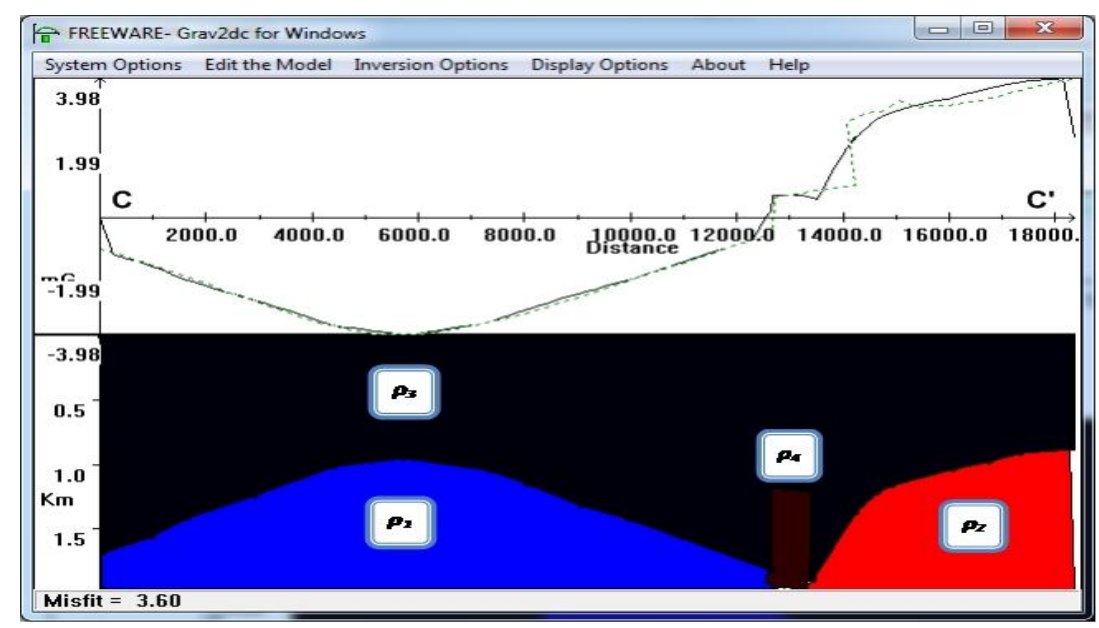

Gambar 9. Pemodelan 2D Penampang C-C'

Ketiga penampang hasil pemodelan 2D di atas dapat diketahui nilai densitasnya yaitu sebgai berikut: untuk penampang A-A' nilai densitasnya adalah $\rho_{1}=2.58 \mathrm{gr} / \mathrm{cm}^{3}, \rho_{2}=2.80$ $\mathrm{gr} / \mathrm{cm}^{3}, \rho_{3}=2.67 \mathrm{gr} / \mathrm{cm}^{3}$, dan $\rho_{4}=2.69 \mathrm{gr} / \mathrm{cm}^{3}$, sedangkan untuk penampang B-B' nilai densitasnya adalah $\rho_{1}=2.58 \mathrm{gr} / \mathrm{cm}^{3}, \rho_{2}=2.82 \mathrm{gr} / \mathrm{cm}^{3}, \rho_{3}=2.67 \mathrm{gr} / \mathrm{cm}^{3}$, dan untuk penampang C-C' nilai densitasnya yaitu $\rho_{1}=2.585 \mathrm{gr} / \mathrm{cm}^{3}, \rho_{2}=2.82 \mathrm{gr} / \mathrm{cm}^{3}, \rho_{3}=2.67 \mathrm{gr} / \mathrm{cm}^{3} \mathrm{dan} \rho_{4}=2.684$ $\mathrm{gr} / \mathrm{cm}^{3}$.

Pada ketiga penampang tersebut terlihat bahwa nilai densitas $\rho_{1}<\rho_{2}<\rho_{3}$, sehingga nilai densitas paling rendah ditunjukkan oleh batuan $\rho_{1}$ yang berwarna biru dengan nilai densitas sebesar $2.58 \mathrm{gr} / \mathrm{cm}^{3}$. Sesuai dengan hasil penelitian [4] bahwa batuan yang memiliki densitas rendah memiliki nilai porositas tinggi. Jika porositas dihubungkan dengan permeabilitas, maka permeablitas berbanding lurus dengan porositas. Hal ini berarti jika porositasnya tinggi maka permeabilitasnya juga tinggi [2] dan [7]. [10] menurunkan rumus dari hukum Darcy bahwa porositas berbanding lurus dengan permeabilitas. Sesuai dengan yang dinyatakan oleh [5] bahwa batuan yang mendomonasi reservoir panasbumi yaitu batuan dengan densitas rendah dan porositas tinggi serta tingkat permeabilitasnya tinggi.

Perubahan suhu reservoir panasbumi per kilometer yaitu sebesar $30^{\circ} \mathrm{C}$ [8]. Reservoir panasbumi berdasarkan hasil penelitian berada pada kedalaman kurang lebih $2 \mathrm{~km}$ sehingga kalau mengacu pada hasil penelitian [1] yang menyatakan bahwa suhu permukaan air panas yang terletak di Desa Blawan adalah $34-48^{\circ} \mathrm{C}$ sehingga dapat dikatakan bahwa dari hasil penelitian daerah Blawan-Ijen berdasarkan data gravity memiliki suhu reservoir sebesar $94-108{ }^{\circ} \mathrm{C}$.

Sedangkan batuan $\rho_{4}$ dengan densitas $2.69 \mathrm{gr} / \mathrm{cm}^{3}$ pada penampang A-A' dan penampang C-C' diinterpretasikan sebagai intrusi. Intrusi merupakan suatu proses yang terjadi akibat adanya aktifitas magma yang berada di bawah permukaan bumi yang diakibatkan adanya tekanan dan temperatur yang sangat tinggi dari dalam bumi.

Di bawah ini adalah gambar penampang 3D seperti yang terlihat pada Gambar 10 berikut. 


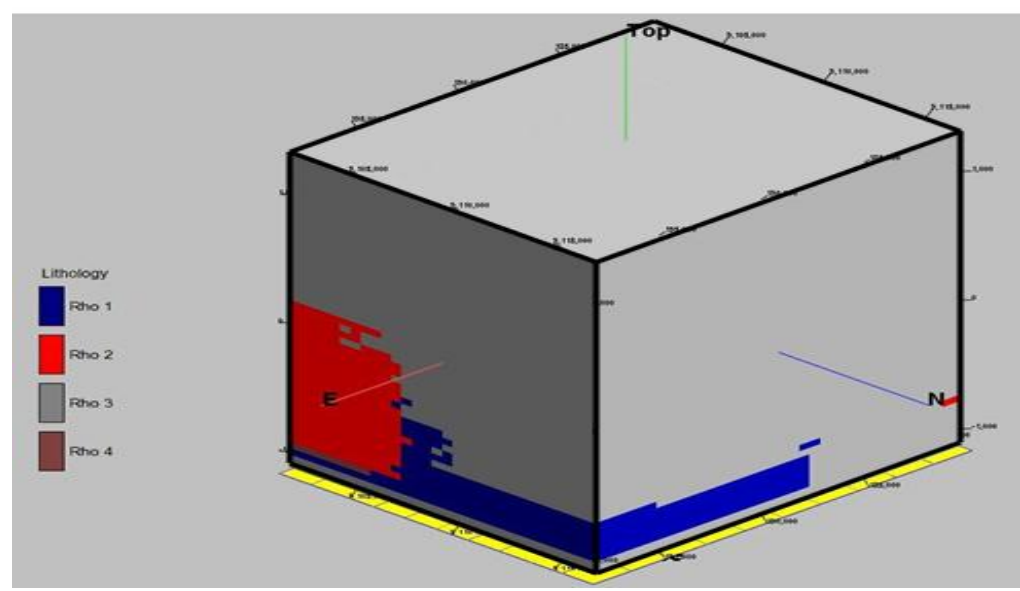

Gambar 10. Pemodelan 3D

Gambar di atas merupakan pemodelan 3D yaitu gabungan antara penampang A-A', B-B' dan penampang C-C' dengan volume $\rho_{1}$ yang diidentifikasi sebagai reservoir panasbumi sebesar 101.20 juta $\mathrm{m}^{3}$. Reservoir panasbumi didominasi oleh batuan $\rho_{1}$. Hal ini sesuai dengan hasil pemodelan $2 \mathrm{D}$ yang merupakan batuan $\rho_{l}$ memiliki nilai densitas lebih rendah.

\section{KESIMPULAN}

Dapat diketahui dari hasil pengolahan data, pemodelan 2D dan 3D serta analisis anomali Bouger di daerah Blawan-Ijen dapat disimpulkan bahwa dari ketiga penampang tersebut terlihat nilai densitas paling rendah ditunjukkan oleh batuan $\rho_{1}$ yang berwarna biru dengan nilai densitas sebesar $2.58 \mathrm{gr} / \mathrm{cm}^{3}$ yang merupakan reservoir panasbumi dengan porositas tinggi dan tingkat permeabilitas tinggi dengan volume sebesar 101.20 juta $\mathrm{m}^{3}$.

\section{DAFTAR PUSTAKA}

[1] Afandi, A. 2013. Identifikasi Reservoar Panasbumi Dengan Metode Geomagnetik Darerah Blawan Kecamatan Sempol Kabupaten Bondowoso. Tesis, Jurusan Fisika. Universitas Brawijaya Malang.

[2] Hazen, A., 1893. Some Physical Proerties Of Sands And Gravels With Special Reference To Their Use In Filtration. Health, Boston.

[3] Hidayat, N dan Basid, A., 2011. Analisis Anomali Gravitasi Sebagai Acuan Dalam Penentuan Struktur Geologi Bawah Permukaan Dan Potensi Geothermal, Jurnal Neutrino, Vol. 4, No. 1.

[4] Sanny, T. A., Handayani. G., Rizal. 2000. Pengaruh Porositas dan Saturasi Pada Kecepatan Getaran P dan Faktor Kualitas Q. Jurnal Geofisika No2, 30-56.

[5] Santoso, D. 2002. Pengantar Geofisika. Institut Teknologi Bandung: Bandung.

[6] Setyaningsih, W, 2011. Potensi Lapangan Panasbumi Gedongsongo Sebagai Sumber Energi Alternatif, Jurnal Geografi, Vol. 8, No. 1. 
[7] Slichter, C. S., 1992. Theoretical investigation of the motion of Ground Waters, U. S. Geological Survey Water Supply Paper 67, Washington, D. C.

[8] Suparno, S., 2009. A Present From The Heart Of The Earth, FMIPA-UI, Jakarta.

[9] Telford, W.M., Geldart, L.P., Sheriff, R.E., Keys, D.A. 1976. Applied Geophysics. Cambridge University Press. New York.

[10]Todd, D K., 1959. Ground Water Hydrology. Toppan Company, Ltd., Tokyo.

[11] Utama, A. P., A. Dwinanto, M. Hikmi, R. Irsamukhti, and Situmorang, 2012. Green Field Geothermal Systems in Java, Indonesia. Proceedings, Geothermal Workshop. InstitutTeknologi Bandung. Bandung, Indonesia.

[12] Wardana, D. 2008. Penelitian Gayaberat di Daerah Perbatasan Cekungan Bogor dan Cekungan jawa Barat Utara. Pusat Penelitian Geoteknologi LIPI. Bandung. 